\title{
Effect of foot load changes on foot arch evaluation using foot pressure distribution data
}

\author{
Kazuya Imaizumi*, Yumi Iwakami, Kazuhiko Yamashita \\ From 4th Congress of the International Foot and Ankle Biomechanics (i-FAB) Community \\ Busan, Korea. 8-11 April 2014
}

\section{Background}

The foot arch serves important functions in regard to shock absorption and the action of walking. Simple and quantitative classification of foot arch types such as flat foot and high arch would be helpful in health support for the elderly. The present authors have developed a classification system for foot arch type showing high reliability using foot pressure distribution data [1,2]. However, effect of foot load changes on foot arch evaluation remains unclear. The aim of this study was to investigate the effect of foot load changes on foot arch evaluation using foot pressure distribution data.

\section{Method}

We conducted a field test involving elderly individuals. Foot pressure distribution data were obtained by the field test with elderly subjects standing on 1 leg and 2 legs. A total of 44 healthy elderly Japanese subjects ( 2 males, 42 females) attended sessions on foot care in Tokyo. Their mean age was $70.7 \pm 7.0$ years, mean height was $153.1 \pm 5.5 \mathrm{~cm}$, and mean weight was $49.9 \pm 4.3 \mathrm{~kg}$. Subjects were first requested to stand on both legs with eyes open. When subjects were adjudged stable in the standing position, digital foot pressure distribution data were obtained by using MAT-SCAN (Nitta Corporation, Japan).

Subjects were next requested to stand on their right leg only with eyes open, and data were obtained as above. Based on our previous study [2], mfp under both bilateral and unilateral stance was calculated. Subjects were categorized into 3 groups according to data from bilateral stance: high arch, normal arch, and flat foot. Paired t-test for $\mathrm{mfp}$ between the 2 stances was implemented for all 3 groups. The level of significance of the test was set at $5 \%$.

* Correspondence: k-imaizumi@thcu.ac.jp

Division of Healthcare Informatics, Faculty of Healthcare, Tokyo Healthcare University, Tokyo, 154-8568, Japan 


\section{References}

1. Imaizumi K, Iwakami Y, Yamashita K: Analysis of foot pressure distribution data for the evaluation of foot arch type. Proceedings of 33rd Annual International Conference of the IEEE EMBC 2011, 7388-7392.

2. Imaizumi K, Iwakami Y, Yamashita K, Hiejima Y: Development of an evaluation system for foot arch type of the elderly by using foot pressure distribution data. Proceedings of 33rd Annual International Conference of the IEEE EMBC 2012, 4859-4862.

doi:10.1186/1757-1146-7-S1-A114

Cite this article as: Imaizumi et al: Effect of foot load changes on foot arch evaluation using foot pressure distribution data. Journal of Foot and Ankle Research 2014 7(Suppl 1):A114.

Submit your next manuscript to BioMed Central and take full advantage of:

- Convenient online submission

- Thorough peer review

- No space constraints or color figure charges

- Immediate publication on acceptance

- Inclusion in PubMed, CAS, Scopus and Google Scholar

- Research which is freely available for redistribution

Submit your manuscript at www.biomedcentral.com/submit 